\title{
SEEING THE WORLD
}




\section{S PRINCETON STUDIES IN CULTURAL SOCIOLOGY \\ Paul J. DiMaggio, Michèle Lamont, \\ Robert J. Wuthnow, and Viviana A. Zelizer, \\ Series Editors}

A list of titles in this series appears at the back of the book. 


\section{SEEING THE WORLD}

How US Universities Make Knowledge in a Global Era

Mitchell L. Stevens,

Cynthia Miller-Idriss,

and Seteney Shami

Princeton University Press

Princeton and Oxford 
Copyright @ 2018 by Princeton University Press

Published by Princeton University Press,

41 William Street, Princeton, New Jersey 08540

In the United Kingdom: Princeton University Press,

6 Oxford Street, Woodstock, Oxfordshire OX20 1TR

press.princeton.edu

Jacket art courtesy of Shutterstock

All Rights Reserved

ISBN 978-0-691-15869-3

Library of Congress Control Number: 2017945421

British Library Cataloging-in-Publication Data is available

This book has been composed in Baskerville 10 Pro and Eurostile LT Std

Printed on acid-free paper. $\infty$

Printed in the United States of America

109876554321 
FOR STUDENTS OF PLACES, AND THEIR MENTORS 
If you think of a university as sort of like a kaleidoscope-all the pieces-I think the kaleidoscope is turning, as we speak, and the question of what the patterns are going to be when it stops turning is an open one.

-POLITICAL SCIENTIST, SENIOR INTERNATIONAL OFFICER 